\title{
Short communication: Role of Mycoplasma arginini in mastitis caused by Streptococcus dysgalactiae
}

\author{
Laszlo Stipkovits, ${ }^{*} \dagger^{1}$ Maria Somogyi, $† \ddagger$ Balazs Asvanyi, $\ddagger$ Agnes Toth, $\ddagger$ and Susan Szathmary $¥ \S$ \\ ${ }^{*}$ Carlsbad Research Organization, Lucsony u. 15-17, 9200 Mosonmagyarovar, Hungary \\ †RT-Europe Research Center, Pozsonyi ut 88, 9200 Mosonmagyarovar, Hungary \\ $\ddagger$ GalenBio Kft, Lucsony u.15-17, 9200 Mosonmagyarovar, Hungary \\ §GalenBio Inc., 1949 Kellogg Ave., Carlsbad, CA 92008-6582
}

\section{ABSTRACT}

We performed a comparative study on the development of mastitis induced by Mycoplasma arginini or Streptococcus dysgalactiae after challenging the cows. Mycoplasma arginini did not cause any clinical symptoms on its own, resulting in only a transient increase of somatic cell count (SCC; increase ranging from 0.5 $\times 10^{6}$ to $0.8 \times 10^{6}$ cells $/ \mathrm{mL}$ ) and a slight decrease of milk production (10\%) for 5 d. In contrast, Strep. dysgalactiae induced more severe clinical signs in animals and SCC increased to $1.60 \times 10^{6}$ to $2.11 \times 10^{6}$ cells/ $\mathrm{mL}$ for $10 \mathrm{~d}$. In addition, milk production decreased (22.9 to $27.0 \%$ ) for $10 \mathrm{~d}$. After 3 mo (2 mo after the first challenge), animals that were challenged previously with $M$. arginini were rechallenged with Strep. dysgalactiae. Severe clinical mastitis developed, with very high SCC $\left(5.00 \times 10^{6}\right.$ to $21.5 \times 10^{6}$ cells $\left./ \mathrm{mL}\right)$, and a very significant reduction of milk production (28.6 to $68.7 \%$ ), which lasted more than 4 wk, was observed. The severe clinical mastitis developed not only in cows inoculated with Strep. dysgalactiae and M. arginini in the same udder quarter but also in cows infected in the quarter previously not challenged with mycoplasma. Cows challenged first with Strep. dysgalactiae and rechallenged with $M$. arginini 2 mo later developed only slight changes in both SCC and milk production, similar to those when the cows were challenged with $M$. arginini alone. We conclude that $M$. arginini infection does not cause remarkable mastitis (characterized by decrease in milk production and increase of SCC) but it significantly predisposes animals to infection with Strep. dysgalactiae, leading to severe clinical mastitis. Key words: challenge, Mycoplasma arginini, Streptococcus dysgalactiae, mastitis

Received April 29, 2012.

Accepted November 26, 2012.

${ }^{1}$ Corresponding author: stipkovits@earthlink.net

\section{Short Communication}

The prevalence of mammary gland inflammation is relatively high in dairy cattle. Mastitis causes considerable economic losses through decreased milk yield, impaired milk quality, and increased cost of treatment and veterinary services (Seegers et al., 2003). Mastitis occurs in clinical and subclinical forms. Several bacterial species including Streptococcus agalactiae, Streptococcus uberis, Streptococcus dysgalactiae, Corynebacterium bovis, and Staphylococcus aureus (Lee et al., 2008) are responsible for causing mastitis (Zhao and Lacasse, 2008). Among the Mycoplasma species, Mycoplasma bovis is reported very frequently as a causative agent of mastitis worldwide (Nicholas et al., 2007). Other Mycoplasma species, such as Mycoplasma alkalescens (Hirose et al., 2001), Mycoplasma leachii (Alexander et al., 1985), Mycoplasma bovigenitalium (Roy et al., 2008), Mycoplasma californicum (Mackie et al., 1982), Mycoplasma canadense (Infante-Martínez et al., 1999), and Mycoplasma verecundum (Higuchi et al., 2011) less frequently cause mastitis. Other Mycoplasma species (e.g., Mycoplasma arginini) are not regarded as etiological agents of mastitis; nevertheless, they are frequently recovered from bulk tank milk (Fox et al., 2005). Therefore, it is important to study the direct effect of $M$. arginini on the udders of cows and the influence of $M$. arginini infection on subsequent Strep. dysgalactiae challenge.

The experimental cows originated from a herd consisting of 500 Holstein-Friesian cows. All animals were examined serologically for the presence of $M$. bovis antibodies using an $M$. bovis ELISA kit (Chekit- $M$. bovis sero; Bommeli Diagnostics, Liebefeld-Bern, Switzerland). In addition to this, nasal swabs, milk samples collected from all quarters of the udder, and vaginal swabs taken from 20 cows were cultured in medium B (Erno and Stipkovits, 1973) for the presence of mycoplasmas. Tubes containing $2 \mathrm{~mL}$ of broth inoculated with samples were incubated for $10 \mathrm{~d}$ at $37^{\circ} \mathrm{C}$. On d 3, 7 , and $10,10 \mu \mathrm{L}$ of broth culture was spread on agar plates that were also incubated for $10 \mathrm{~d}$ at $37^{\circ} \mathrm{C}$. Agar 
plates were regularly examined under the microscope for the presence of mycoplasma colonies. Inoculated broth samples were tested after $24 \mathrm{~h}$ of incubation by PCR using primers specific for mycoplasma and primers specific for M. bovis (Tenk et al., 2006).

Twelve cows in middle of second lactation were selected for the experiment. Before the study, all cows were retested for the presence of mycoplasmas as described earlier; no mycoplasmas were detected. Cows were divided into 3 groups of 4 animals each in such a way that the average milk production of a group did not differ statistically from that of the other groups during the $5 \mathrm{~d}$ before challenge. The cows were labeled $\mathrm{A}, \mathrm{B}, \mathrm{C}$, and D in group $1 ; \mathrm{E}, \mathrm{F}, \mathrm{G}$, and $\mathrm{H}$ in group 2; and $\mathrm{I}, \mathrm{J}, \mathrm{K}$, and $\mathrm{L}$ in group 3.

The cows of group 1 were challenged with $5 \mathrm{~mL}$ of a 48-h-old $M$. arginini culture (strain 65 ), which was isolated from the serum of a 1-d-old calf (Stipkovits et al., 1975). The strain was cloned 3 times, lyophilized, and stored at $-70^{\circ} \mathrm{C}$; it was cultured every 4 to $5 \mathrm{yr}$. Before challenge, the broth culture was diluted 1:100 with PBS. The concentration of the inoculum was 1.3 $\times 10^{6} \mathrm{cfu} / \mathrm{mL}$, and cows were inoculated in the milk cistern of the left rear (LR) quarter of the udder after the morning milking using a 20-cm-long catheter $3 \mathrm{~mm}$ in diameter. After inoculation, the udder was massaged gently. The protocol of the animal experiment was approved by the Animal Research and Care Committee of the Carlsbad Research Organization Ltd. (Mosonmagyarovar, Hungary), and animal care and experimentation were carried out in accordance with the institutional and national guidelines. Cows of group 2 were inoculated in the cistern of the LR quarter with $5.0 \mathrm{~mL}$ of a 24 -h-old broth culture of Strep. dysgalactiae diluted $1: 100$ in PBS $\left(5.3 \times 10^{6} \mathrm{cfu} / \mathrm{mL}\right)$. Animals in group 3 (control group) were inoculated with $5 \mathrm{~mL}$ of sterile PBS into the LR quarter. The groups were kept in separate air spaces. Feeding and maintenance were the same in all 3 groups, but care and milking of cows in different groups were performed by different personnel.

For $5 \mathrm{~d}$ before and $15 \mathrm{~d}$ after challenge, the cows were examined clinically every day after the morning milking. The presence of clinical signs was scored as follows: 1 = udder was swollen or painful or the local temperature on the udder surface was increased. Milk production of cows was measured in the morning and evening. The SCC of milk samples obtained from each quarter at the morning milking was checked. Milk quality was recorded every morning and scored as follows: score $1=$ color of the milk had become yellowish or brownish; score $2=$ milk contained flakes, and score 3 $=$ milk coagulated. In group 1, the mycoplasma counts of milk samples obtained during the morning milking from each quarter were checked. Similarly, in group 2 the bacterial count of milk samples was tested. Milk samples from cows of group 3 were also tested for the presence of mycoplasma and bacteria.

Two months after the end of the first experiment (first challenge), the cows were rechallenged as follows: In group 1, cows A and B were challenged in the LR quarter and cows $\mathrm{C}$ and $\mathrm{D}$ were challenged in the right rear (RR) quarter with $5 \mathrm{~mL}$ of 1:100 diluted 24-h-old broth culture of Strep. dysgalactiae $\left(6.5 \times 10^{6} \mathrm{cfu} / \mathrm{mL}\right.$. In group 2, cows $\mathrm{E}$ and $\mathrm{F}$ were challenged in the $\mathrm{LR}$ quarter and cows $\mathrm{G}$ and $\mathrm{H}$ in the RR quarter with a 1:100 diluted 49-h-old $M$. arginini broth culture $(3.9 \times$ $10^{6} \mathrm{cfu} / \mathrm{mL}$ ) in the same way as in the previous experiment. Clinical examination, milk production recording, and the checking of milk SCC and milk quality were performed as described previously.

Two months after the start of the rechallenge experiment, the animals were euthanized and examined for pathological lesions in the internal organs and udder. Lung lesions were scored as follows: score $1=$ area of lesions was $<50 \%$ of the lobe, and score $2=$ lesions extended to $>50 \%$ of the lobe. The udder quarters were scored in a similar manner. Attempts were made to isolate M. arginini and Strep. dysgalactiae from all lobes of the lung, from the liver, spleen, and kidney, and from all udder quarters.

The clinical scores, scores of milk changes, and the isolation of mycoplasmas from the organs of animals in the different groups were compared by using the Chisquared test. The quantities of milk produced in the groups during 5 -d periods were compared by Student's $t$-test.

The cows used for the studies originated from a herd that was serologically negative for $M$. bovis by ELISA test and negative for $M$. bovis and M. arginini by culture and PCR. Nasal swabs, milk samples collected from all quarters of the udder, and vaginal swabs taken from 20 cows selected for studies proved to be negative by culturing and by PCR using primers specific for mycoplasmas and primers specific for M. bovis.

In group 1, we observed no swelling or pain of the udder or increased local temperature of the udder surface during the 15-d observation period after challenge with $M$. arginini. In group 2, 3 animals showed slight swelling of the udder with mild pain and increased local temperature of the udder surface for 2 to $3 \mathrm{~d}$ between $\mathrm{d}$ 6 and 10; scores varied between 5 and 9 (Table 1). No clinical symptoms were present in animals of group 3 .

Milk production of cows was assessed from $d-5$ to $d$ -1 (prechallenge milk production), and no differences were recorded between groups 1, 2, and 3 based on Student's $t$-test. Following challenge, however, milk production in group 1 was 3.6 and $8.4 \%$ lower rom d 1 to 
Table 1. Clinical signs and milk production on d 1 to 15 postchallenge of cows challenged in the udder with Mycoplasma arginini or Streptococcus dysgalactiae

\begin{tabular}{|c|c|c|c|c|}
\hline \multirow[b]{3}{*}{ Group and challenge agent } & \multirow[b]{3}{*}{ Clinical sign } & \multicolumn{3}{|c|}{ Days postchallenge } \\
\hline & & 1 to 5 & 6 to 10 & 11 to 15 \\
\hline & & \multicolumn{3}{|c|}{ Clinical sign score } \\
\hline \multirow[t]{3}{*}{ Group 1: $M$. arginini } & Udder swelling & 0 & 0 & 0 \\
\hline & Udder pain & 0 & 0 & 0 \\
\hline & Increased udder temperature & 0 & 0 & 0 \\
\hline \multirow[t]{3}{*}{ Group 2: Strep. dysgalactiae } & Udder swelling & 0 & 6 & 0 \\
\hline & Udder pain & 0 & 9 & 0 \\
\hline & Increased udder temperature & 0 & 5 & 0 \\
\hline \multirow[t]{4}{*}{ Group 3: control } & Udder swelling & 0 & 0 & 0 \\
\hline & Udder pain & 0 & 0 & 0 \\
\hline & Increased udder temperature & 0 & 0 & 0 \\
\hline & $\begin{array}{l}\text { Prechallenge milk } \\
\text { production }^{1}(\mathrm{~L})\end{array}$ & \multicolumn{3}{|c|}{ Postchallenge milk production (L) } \\
\hline Group 1: M. arginini & 221.60 & $\begin{array}{l}212.6 \\
(95.5 \%)^{2} \\
(95.6 \%)^{3}\end{array}$ & $\begin{array}{l}200.4 \\
(90.4 \%) \\
(90.4 \%)\end{array}$ & $\begin{array}{l}216.3 \\
(98.0 \%) \\
(98.0 \%)\end{array}$ \\
\hline Group 2: Strep. dysgalactiae & 224.60 & $\begin{array}{l}177.7 \\
(79.1 \%) \\
(79.1 \%)\end{array}$ & $\begin{array}{l}164.0 \\
(73.0 \%) \\
(73.0 \%)\end{array}$ & $\begin{array}{l}216.6 \\
(96.4 \%) \\
(95.8 \%)\end{array}$ \\
\hline Group 3: control & 224.4 & $\begin{array}{l}222.5 \\
(99.2 \%)^{4}\end{array}$ & $\begin{array}{l}221.6 \\
(98.8 \%)^{4}\end{array}$ & $\begin{array}{l}220.8 \\
(98.4 \%)^{4}\end{array}$ \\
\hline
\end{tabular}

${ }^{1}$ Total milk produced (L) during 5 d before challenge.

${ }^{2}$ Milk production compared with that prechallenge.

${ }^{3}$ Milk production compared with that of control group.

${ }^{4}$ No effect on milk production.

5 and from d 6 to 10, respectively, compared with that in the control group (group 3). The quantity of milk obtained in group 2 was 19.3 and $24.8 \%$ lower from d 1 to 5 and from d 6 to 10 , respectively, compared with that in group 3 (Table 1 ).

The SCC of milk before challenge ranged between $0.06 \times 10^{6}$ and $0.39 \times 10^{6}$ cells $/ \mathrm{mL}$. On d 3 after challenge, a slight increase of SCC was recorded in the inoculated LR quarters of group 1 cows, reaching an average of $1.25 \times 10^{6}$ and $1.30 \times 10^{6}$ cells $/ \mathrm{mL}$ from $\mathrm{d}$ 1 to 5 and from d 6 to 10 , respectively. In the period from d 11 to 15 , SCC decreased to $0.55 \times 10^{6}$ cells/ $\mathrm{mL}$. No increase of SCC was observed in milk samples from other quarters - left fore $(\mathbf{L F}), \mathrm{RR}$, and right fore (RF). In group 2, on d 3 after challenge, SCC started to increase and reached values of $1.60 \times 10^{6}, 2.11 \times 10^{6}$, and $0.75 \times 10^{6}$ cells $/ \mathrm{mL}$ between $\mathrm{d} 1$ and $5, \mathrm{~d} 6$ and 10 , and $\mathrm{d} 11$ and 15, respectively. Somatic cell counts exceeding $0.37 \times 10^{6}$ cells $/ \mathrm{mL}$ were not recorded in milk samples from the uninoculated LF, RR, or RF quarters of this group in any of the postchallenge observation periods (Table 2). In the control group (group 3), the highest SCC was only $0.36 \times 10^{6}$ cells $/ \mathrm{mL}$.

The quality of all milk samples obtained in group 1 during the $15-\mathrm{d}$ postchallenge observation period was normal (same as in the control group). In group 2, the color of milk produced in the period from d 6 to 10 was yellowish and flakes were sometimes observed in it; the appearance of milk from cows in group 2 later returned to normal.

After rechallenge of cows A and B with Strep. dysgalactiae in the same quarter (LR) as the first challenge (M. arginini), severe clinical signs were observed. The inoculated quarters became swollen and painful, and the temperature of the udder surface increased. Scores of these signs ranged between 3 and 10 in the observation period (Table 3 ). These signs were also present between 25 and $30 \mathrm{~d}$ postchallenge. The animals became depressed and their appetite decreased. Similar symptoms were observed in cows C and D (inoculated with Strep. dysgalactiae in the RR quarter, a quarter not previously inoculated with $M$. arginini; Table 3 ). No or only very mild clinical signs were noticed in cows E, F, G, and H of group 2 (challenged first with Strep. dysgalactiae and rechallenged with $M$. arginini) and in cows of the control group (group 3).

Milk production of cows A and B (group 1) from d 1 to 5 was $29.4 \%$ lower than that of group $3(P<0.001)$. In the periods from d 6 to 10 and from d 11 to 15 , milk production decreased even more, with reductions of $37.1 \%(P<0.001)$ and $51.4 \%(P>0.00 .5)$ compared with that of cows of group 3. Similar reductions of milk 
Table 2. Somatic cell counts $\left(\times 10^{6}\right.$ cells $\left./ \mathrm{mL}\right)$ in milk of cows challenged in the udder with Mycoplasma arginini or Streptococcus dysgalactiae

\begin{tabular}{llccc}
\hline & & \multicolumn{3}{c}{ Days postchallenge } \\
\cline { 3 - 5 } Group and challenge agent & Udder quarter & 1 to 5 & 6 to 10 & 11 to 15 \\
\hline Group 1: $M$. arginini & Left fore & 0.30 & 0.35 & 0.35 \\
& Left rear & 1.25 & 1.30 & 0.55 \\
& Right fore & 0.32 & 0.33 & 0.34 \\
Group 2: Strep. dysgalactiae & Right rear & 0.35 & 0.36 & 0.34 \\
& Left fore & 0.36 & 0.33 & 0.34 \\
& Left rear & 1.60 & 2.11 & 0.55 \\
Group 3: PBS (control) & Right fore & 0.36 & 0.35 & 0.37 \\
& Right rear & 0.33 & 0.33 & 0.34 \\
& Left fore & 0.35 & 0.36 & 0.32 \\
& Left rear & 0.33 & 0.34 & 0.34 \\
& Right fore & 0.33 & 0.34 & 0.34 \\
& Right rear & 0.34 & 0.36 & 0.34 \\
\hline
\end{tabular}

${ }^{1}$ Left rear quarter challenged with M. arginini, Strep. dysgalactiae, or PBS, depending on group.

production were recorded in cows $\mathrm{C}$ and $\mathrm{D}(26.7,36.3$, and $47.4 \%$ in d 1 to 5,6 to 10 , and 11 to 15 , respectively). No statistically significant decrease in milk production was noted between cows rechallenged with Strep. dysgalactiae into quarters previously inoculated (or not) with $M$. arginini. Milk production of cows $\mathrm{E}$, $\mathrm{F}, \mathrm{G}$, and $\mathrm{H}$ decreased only slightly, by 2.5 to $5.8 \%$ (E and $\mathrm{F}$ ) or 0.9 to $1.5 \%$ ( $\mathrm{G}$ and $\mathrm{H}$ ) in the different periods of observation compared with that of the control group (Table 4).

From d 2 after Strep. dysgalactiae rechallenge of cows $\mathrm{A}$ and $\mathrm{B}$ into the LR quarter first inoculated with $M$. arginini, we recorded a significant increase of SCC, reaching $3.25 \times 10^{6}$ to $21.50 \times 10^{6}$ cells $/ \mathrm{mL}$. Increased $\mathrm{SCC}$ was recorded in the milk of the $\mathrm{LF}, \mathrm{RF}$, and RR quarters as well. A significant increase of SCC was recorded in all udder quarters of cows $\mathrm{C}$ and $\mathrm{D}$ (challenged with Strep. dysgalactiae into the udder quarter not inoculated with $M$. arginini at first challenge). In group 2, a slight increase was noticed only in the udder quarters inoculated with $M$. arginini, regardless of whether or not they were previously challenged with Strep. dysgalactiae. In milk from the udder quarters of the control cows, the SCC never exceeded $0.40 \times 10^{6}$ cells/mL (Table 5).

The quality of all milk samples obtained from the cows of group 1 changed very significantly $4 \mathrm{~d}$ postchallenge. Milk color became yellowish and then yellow, and many flakes were seen in the milk, which sedimented within a few minutes. From d 6 to 10 and from d 11

Table 3. Scores of clinical signs of cows rechallenged in the udder with Mycoplasma arginini or Streptococcus dysgalactiae

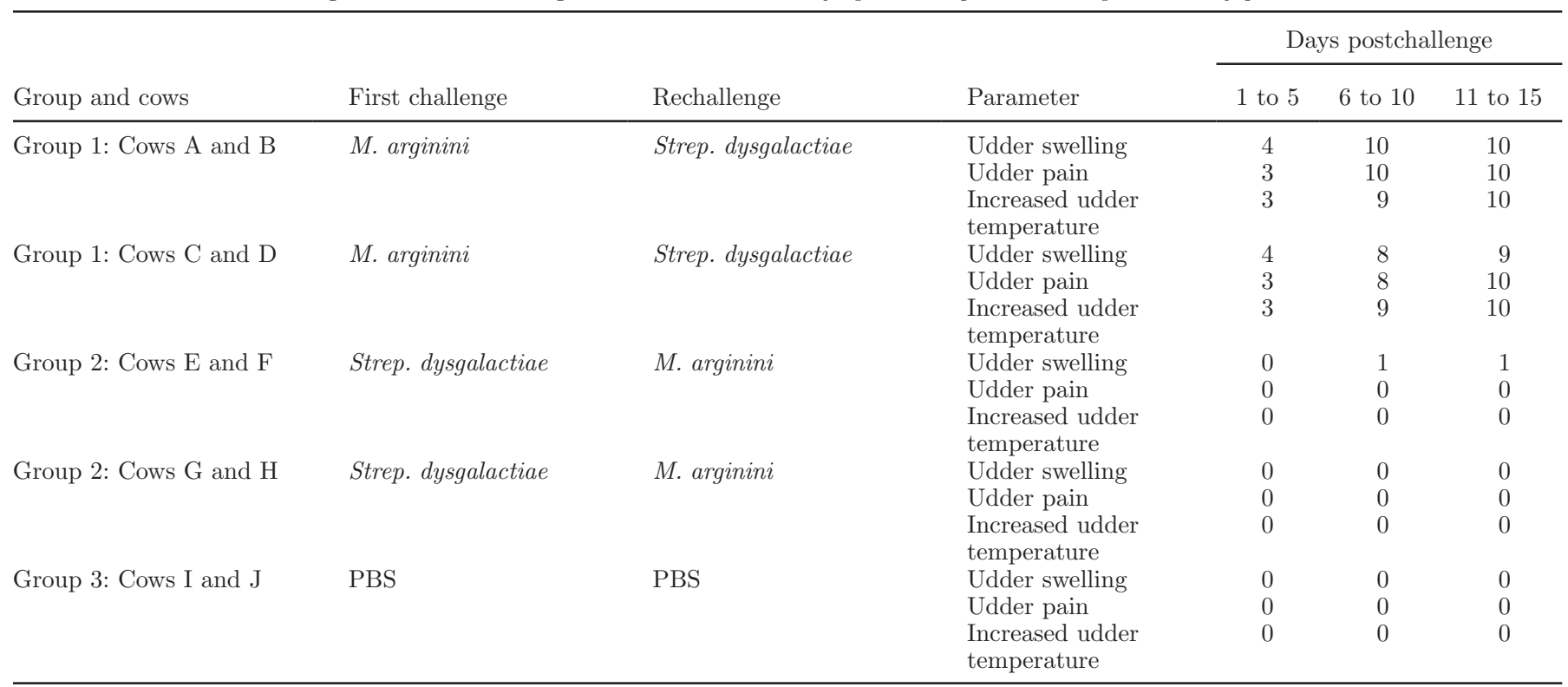


Table 4. Milk production of cows rechallenged in the udder with Mycoplasma arginini or Streptococcus dysgalactiae

\begin{tabular}{|c|c|c|c|c|c|c|}
\hline \multirow[b]{2}{*}{ Group } & \multirow[b]{2}{*}{ First challenge } & \multirow[b]{2}{*}{ Rechallenge } & \multirow{2}{*}{$\begin{array}{l}\text { Prechallenge milk } \\
\text { production }^{1}(\mathrm{~L})\end{array}$} & \multicolumn{3}{|c|}{ Days postchallenge } \\
\hline & & & & 1 to 5 & 6 to 10 & 11 to 15 \\
\hline Group 1: Cows A and B & M. arginini & Strep. dysgalactiae & 88.6 & $\begin{array}{l}60.8 \\
(68.6 \%)^{2} \\
68.7 \%^{3}\end{array}$ & $\begin{array}{c}52.8 \\
(59.6 \%) \\
60.0 \%\end{array}$ & $\begin{array}{c}37.2 \\
(42.0 \%) \\
43.5 \%\end{array}$ \\
\hline Group 1: Cows C and D & M. arginini & Strep. dysgalactiae & 89.6 & $\begin{array}{l}63.2 \\
(70.5 \%) \\
71.4 \%\end{array}$ & $\begin{array}{c}54.1 \\
(60.4 \%) \\
61.4 \%\end{array}$ & $\begin{array}{c}40.7 \\
(45.4 \%) \\
47.5 \%\end{array}$ \\
\hline Group 2: Cows $\mathrm{G}$ and $\mathrm{H}$ & Strep. dysgalactiae & M. arginini & 89.2 & $\begin{array}{l}85.5 \\
(95.9 \%) \\
96.6 \%\end{array}$ & $\begin{array}{l}85.3 \\
(95.6 \%) \\
96.8 \%\end{array}$ & $\begin{array}{l}84.5 \\
(94.7 \%) \\
98.7 \%\end{array}$ \\
\hline Group 3: Cows I and J & PBS & PBS & 90.2 & $\begin{array}{l}88.5 \\
(98.1 \%)\end{array}$ & $\begin{array}{l}88.1 \\
(97.7 \%)\end{array}$ & $\begin{array}{l}85.6 \\
(94.9 \%)\end{array}$ \\
\hline
\end{tabular}

${ }^{1}$ Total milk produced (L) during $5 \mathrm{~d}$ before challenge.

${ }^{2}$ Milk production compared with that prechallenge.

${ }^{3}$ Milk production compared with control group.

to 15 postchallenge, some milk samples coagulated. At 1 mo postchallenge, the milk showed a similar appearance to that at d 11 to 15 postchallenge.

No lesions were present in the lung, spleen, liver, or kidney of cows A and B, although severe lesions were found in all udder quarters of these cows. The lesion score of the udders was 14. Similarly, no lesions were seen in the inner organs of cows C and D but severe lesions were recorded in their udders. The lesion score was 12 . No lesions were observed in any organs or in the udders of cows of groups 2 and 3.

Mycoplasmas were detected in the lungs of all cows of group 1, and the spleen of cows A and B and the kidney of cow D were also positive for mycoplasmas.

Table 5. Somatic cell counts $\left(\times 10^{6}\right.$ cells $\left./ \mathrm{mL}\right)$ in the milk of cows rechallenged in the udder with Mycoplasma arginini or Streptococcus dysgalactiae

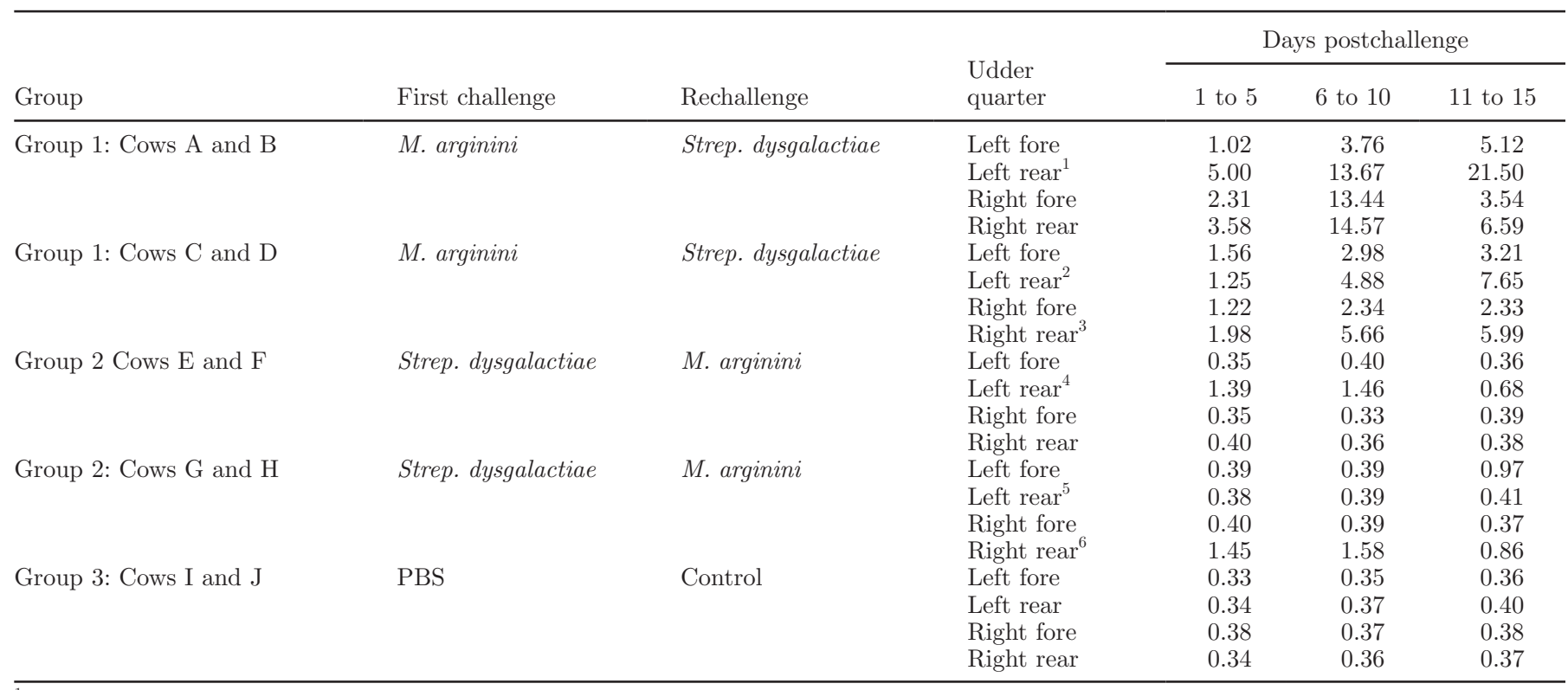

${ }^{1}$ Left rear quarters previously challenged with M. arginini and then later not challenged with Strep. dysgalactiae.

${ }^{2}$ Left rear quarters previously challenged with M. arginini and then later challenged with Strep. dysgalactiae.

${ }^{3}$ Right rear quarter previously not challenged with M. arginini and then later challenged with Strep. dysgalactiae.

${ }^{4}$ Left rear quarters previously challenged with Strep. dysgalactiae and then later challenged with M. arginini.

${ }^{5}$ Left rear quarters previously challenged with Strep. dysgalactiae and then later not challenged with M. arginini.

${ }^{6}$ Right rear quarters previously not challenged with Strep. dysgalactiae and then later challenged with M. arginini. 
Mycoplasma arginini was isolated from the LR quarters of cows A, B, C, and D, as well as from the LR quarters of cows $\mathrm{E}$ and $\mathrm{F}$ and the RR quarters of cows $\mathrm{G}$ and $\mathrm{H}$. The concentration of $M$. arginini in the milk samples varied between $2.4 \times 10^{2}$ and $5.1 \times 10^{4} \mathrm{cfu} / \mathrm{mL}$. No Strep. dysgalactiae was found in any of the inner organs of any cow. Streptococcus dysgalactiae was present in a high concentration in all udder quarters of cows A, $\mathrm{B}, \mathrm{C}$, and $\mathrm{D}$, but not in any of the udder quarters of groups 2 and 3.

Mycoplasma arginini is frequently isolated from various animal species affected with different pathological conditions; for example, from cattle with respiratory disease (Thomas et al., 2002; Ayling et al., 2004). It has been demonstrated that $M$. arginini can persist for a long time under different environmental conditions (Nagatomo et al., 2001).

Until now, no data have been available regarding mastitis caused by $M$. arginini, although this species is frequently detected in bulk milk originating from herds affected with mastitis of different etiologies (Fox et al., 2005; Higuchi et al., 2011; Justice-Allen et al., 2011). In this study, only a mild decrease in milk production and a slight increase in SCC were noticed after challenge of cows with M. arginini into the udder, whereas Strep. dysgalactiae induced more remarkable signs of mastitis. However, if the cows were first challenged in the udder with $M$. arginini, mycoplasma infection increased their sensitivity to Strep. dysgalactiae. In such cases, Strep. dysgalactiae caused very severe mastitis (swollen and painful udder with increased local temperature on the udder surface, significant decrease of milk production, very high milk SCC, significant changes in milk characteristics) compared with that when cows were inoculated with Strep. dysgalactiae into the udder without previous $M$. arginini challenge. No such synergistic effect was observed when the cows were challenged with M. arginini after a first challenge with Strep. dysgalactiae. The predisposing effect of $M$. arginini to bacterial infection can be explained by its ability to inhibit the growth of T cells (Komada et al., 1997) and the development of cytotoxic T-cell activity (Claesson et al., 1990), to suppress B-cell differentiation (Foresman et al., 1989), and to induce the secretion of cytokines involved in the inflammatory response (such as tumor necrosis factor $\alpha$ and IL6) by blood monocytes (Herbelin et al., 1994), among other properties.

Detection of $M$. arginini in the tank milk may indicate the frequent appearance of bacterial mastitis in cow herds. Today, most antimastitis drugs generally contain penicillin or its derivatives, which have no effect on mycoplasmas. Therefore, to prevent the predisposing effect of $M$. arginini in the development of bacterial mastitis, we recommend that antimycoplasma drugs also be applied for the control of mastitis.

According to some reports, $M$. arginini infection has been associated with severe disease in humans (Yechouron et al., 1992; Sillis, 1994). In previous studies in our laboratory, we isolated $M$. arginini from the blood of a 23-yr-old man who had suffered from severe eosinophilic fasciitis for about $2 \mathrm{yr}$. After appropriate antibiotic and steroid therapy, the patient recovered (Silló et al., 2012). This individual did not have direct contact with animals but he regularly consumed cow milk. Because $M$. arginini can be present in milk over long periods, contaminated milk could be a source of infection for humans, especially for immunocompromised individuals.

Based on the data obtained in the current study, we conclude that $M$. arginini infection does not produce clinical signs of mastitis but it does predispose cows to development of severe mastitis associated with Strep. dysgalactiae.

\section{REFERENCES}

Alexander, P. G., K. J. Slee, S. McOrist, L. Ireland, and P. J. Coloe. 1985. Mastitis in cows and polyarthritis and pneumonia in calves caused by Mycoplasma species bovine group 7. Aust. Vet. J. $62: 135-136$.

Ayling, R. D., S. E. Bashiruddin, and R. A. Nicholas. 2004. Mycoplasma species and related organisms isolated from ruminants in Britain between 1990 and 2000. Vet. Rec. 155:413-416.

Claesson, M. H., T. Tscherning, M. H. Nissen, and K. Lind. 1990 Inhibitory effect of mycoplasma-released arginase activity in mixed-lymphocyte and tumor cell cultures. Scand. J. Immunol. $32: 623-630$.

Erno, H., and L. Stipkovits. 1973. Bovine mycoplasmas: Cultural and biochemical studies. I. Acta Vet. Scand. 14:436-449.

Foresman, M. D, K. C. Sheehan, and J. E. Swierkosz. 1989. The regulation of murine B cell differentiation. I. Nonspecific suppression caused by Mycoplasma arginini. Cell. Immunol. 123:354-372.

Fox, L. K., K. J. Kirk, and A. Britten. 2005. Mycoplasma mastitis: A review of transmission and control. J. Vet. Med. B Infect. Dis. Vet. Public Health 52:153-160.

Herbelin, A., E. Ruuth, D. Delorme, C. Michel-Herbelin, and F. Praz. 1994. Mycoplasma arginini TUH-14 membrane lipoproteins induce production of interleukin-1, interleukin-6, and tumor necrosis factor alpha by human monocytes. Infect. Immun. 62:4690-4694.

Higuchi, H., H. Iwano, K. Kawai, T. Ohta, T. Obayashi, K. Hirose, N. Ito, H. Yokota, Y. Tamura, and H. A. Nagahata. 2011. Simplified PCR assay for fast and easy mycoplasma mastitis screening in dairy cattle. J. Vet. Sci. 12:191-193.

Hirose, K., Y. Kawasaki, K. Kotani, A. Tanaka, K. Abiko, and H. Ogawa. 2001. Detection of mycoplasma in mastitic milk by PCR analysis and culture method. J. Vet. Med. Sci. 63:691-693.

Infante-Martínez, F., J. Aguado, and D. Eduard-Jasper. 1999. Mastitis outbreak due to Mycoplasma californicum and Mycoplasma canadense in a commercial dairy herd in the state of Jalisco, México. Rev. Latinoam. Microbiol. 41:117-120.

Justice-Allen, A., J. Trujillo, G. Goodell, and D. Wilson. 2011. Detection of multiple Mycoplasma species in bulk tank milk samples using real-time PCR and conventional culture and comparison of test sensitivities. J. Dairy Sci. 94:3411-3419.

Komada, Y., X. L. Zhang, Y. W. Zhou, M. Ido, and E. Azuma. 1997. Apoptotic cell death of human T lymphoblastoid cells induced by arginine deiminase. Int. J. Hematol. 65:129-141. 
Lee, K. H., J. W. Lee, S. W. Wang, L. Y. Liu, M. F. Lee, S. T. Chuan, Y. M. Shy, C. L. Chang, M. C. Wu, and C. H. Chi. 2008. Development of a novel biochip for rapid multiplex detection of seven mastitis-causing pathogens in bovine milk samples. J. Vet. Diagn. Invest. 20:463-471.

Mackie, D. P., H. J. Ball, and E. F. Logan. 1982. Isolation of Mycoplasma californicum from an outbreak of bovine mastitis and the experimental reproduction of the disease. Vet. Rec. 110:578-580.

Nagatomo, H., Y. Takegahara, T. Sonoda, A. Yamaguchi, R. Uemura, S. Hagiwara, and M. Sueyoshi. 2001. Comparative studies of the persistence of animal mycoplasmas under different environmental conditions. Vet. Microbiol. 82:223-232.

Nicholas, R., R. Ayling, and L. McAuliffe. 2007. Mycoplasma mastitis. Vet. Rec. 160:382-383.

Roy, J. P., D. Francoz, and O. Labrecque. 2008. Mastitis in a 7-week old calf caused by Mycoplasma bovigenitalium. Vet. J. 176:403404.

Seegers, H., C. Fourichon, and F. Beaudeau. 2003. Production effects related to mastitis and mastitis economics in dairy cattle herds. Vet. Res. 34:475-491.

Sillis, M. 1994. Mycoplasma arginini-A new human zoonosis? Clin. Infect. Dis. 18:488.
Silló, P., D. Pinter, E. Ostorhazi, M. Mazan, N. Wikonkal, K. Ponyai, D. Volohov, V. Chizikov, S. Szathmary, L. Stipkovits, and S. Karpati. 2012. Eosinophilic fasciitis associated with Mycoplasma arginini infection. J. Clin. Microbiol. 50:1113-1117.

Stipkovits, L., L. Bodon, J. Romváry, and L. Varga. 1975. Direct isolation of mycoplasmas and acholeplasmas from sera and kidneys of calves. Acta Microbiol. Acad. Sci. Hung. 22:45-51.

Tenk, M., A. Balint, L. Stipkovits, J. Biro, and L. Dencso. 2006. Detection of Mycoplasma bovis with an improved PCR assay. Acta Vet. Hung. 54:427-435.

Thomas, A., H. Ball, I. Dizier, A. Trolin, C. Bell, J. Mainil, and A. Linden. 2002. Isolation of mycoplasma species from the lower respiratory tract of healthy cattle and cattle with respiratory disease in Belgium. Vet. Rec. 151:472-476.

Yechouron, A., J. Lefebvre, H. G. Robson, D. L. Rose, and J. G. Tully. 1992. Fatal septicemia due to Mycoplasma arginini: A new human zoonosis. Clin. Infect. Dis. 15:434-438.

Zhao, X., and P. Lacasse. 2008. Mammary tissue damage during bovine mastitis: Causes and control. J. Anim. Sci. 86(Suppl.):57-65. 